\title{
Identification of Post-Harvest Operations Related to the Contamination of Arachis hypogaea L. (Groundnut) by Mycotoxins in the Province of Mayo Kebbi Ouest in the Republic of Chad
}

\author{
Serferbe Signaboubo ${ }^{*}$, Mbakop Nya Christelle ${ }^{1}$, Gapili Naoura ${ }^{2}$ \\ ${ }^{1}$ Research Unit of Applied Botany, University of Dschang, Dschang, Cameroon \\ ${ }^{2}$ Chadian Institute of Agricultural Research for Development, N'Djamena, Chad \\ Email: ${ }^{\star}$ zahiikydidier@yahoo.fr, * signaboubo_serferbe@yahoo.fr
}

How to cite this paper: Signaboubo, S., Christelle, M.N. and Naoura, G. (2021) Identification of Post-Harvest Operations Related to the Contamination of Arachis hypogaea L. (Groundnut) by Mycotoxins in the Province of Mayo Kebbi Ouest in the Republic of Chad. Agricultural Sciences, 12, 406-413.

https://doi.org/10.4236/as.2021.124026

Received: February 16, 2021

Accepted: April 18, 2021

Published: April 21, 2021

Copyright $\odot 2021$ by author(s) and Scientific Research Publishing Inc. This work is licensed under the Creative Commons Attribution International License (CC BY 4.0).

http://creativecommons.org/licenses/by/4.0/ (c) $\underset{\mathrm{By}}{\text { Oi }}$ Open Access

\begin{abstract}
Good practice in post-harvest operations depends on the contamination of groundnuts (Arachis hypogaea) by mycotoxins. The objective of this study is to identify farmers' practices that pose a risk to the post-harvest preservation of the fruits of Arachis hypogaea in the province of Mayo Kebbi Ouest. Data collection was carried out using a farmer survey sheet based on a questionnaire on drying and storage techniques and losses related to groundnut harvesting. The study revealed that the fruits of Arachis hypogaea are dried on the fields and stored in shells or pods in polyethylene bags. The latter can be kept for up to 6 months in the shop (44\%), in the attic (25.3\%), in living quarters (18.7\%) and both in the attic and in houses (12\%). The level of post-harvest losses is due on the one hand to post-harvest diseases $(60 \%)$ and the presence of insects on the crops (32\%) and on the other hand to the germination of seeds (8\%) after the harvest due to heavy rains. This loss on a scale of $2 \%$ to $10 \%$ is $74.7 \%$ and $10 \%$ to $50 \%$ is $25.3 \%$. Drying and storage techniques in these localities represent a risk of mycotoxin contamination of groundnuts. Raising farmers' awareness of harvest management techniques to preserve the sanitary quality of groundnuts would be important.
\end{abstract}

\section{Keywords}

Arachis hypogaea, Post-Harvest Technique, Drying, Storage, Mycotoxin 


\section{Introduction}

Groundnut (Arachis hypogaea L.) is one of the main oil crops in Chad and an important source of oil and protein for her population. It plays an increasingly important role in crop production synthesis [1], with a production of 893,940 tons of shells, i.e. $41.64 \%$ of the production in Central Africa [2]. Groundnuts are cultivated in all the agroecological zones of Chad for their nutritional and commercial value. As a staple food for the Chadian population, its raw consumption and/or derived products has improved the quality of diets [3]. Indeed, its regular consumption prevents cardiovascular and diabetic problems [4], it also helps to reduce severe malnutrition in children [5]. Groundnuts, because of their high adaptive capacity in different agro-ecological zones, would be vulnerable to contamination by mycotoxins produced by saprotrophic fungi. Among the mycotoxins, aflatoxins produced mainly by fungi of the genus Aspergillus are major contaminants [6]. Numerous studies in Benin, Côte d'Ivoire and Nigeria have shown that mycotoxin contamination occurs via pods before, during or after harvest [7]. The level of tolerance of the groundnut variety, soil type, presence of fungi, climatic conditions, agricultural practices, water activity and maturity of the groundnut are the factors that determine the importance of mycotoxins in groundnuts [8]. However, many drying and storage techniques are used to limit fungal growth. According to [6], drying the pods by $30 \%-40 \%$ increases their shelf life. Storing peanuts on a device that allows air to circulate through is likely to reduce the growth of fungi and therefore the production of aflatoxins [9]. Prevention due to contamination and growth of saprotrophic fungi is one of the best ways to limit aflatoxin contamination of peanuts. Despite some knowledge of the dangers of aflatoxin in groundnuts worldwide, little is known about the know-how of Chadian producers to minimize the production and proliferation of mycotoxins. The aim of this study is to identify post-harvest practices likely to favor the proliferation of mycotoxins by groundnuts in the province of Mayo Kebbi Ouest.

\section{Materials and Methods}

The study was carried out in West Mayo Kebbi. The West Mayo Kebbi Plain is in the south-west of Chad, in the middle of the Sahelo-Sudanian region. The climate is tropical semi-humid ( $900 \mathrm{~mm}$ to $1200 \mathrm{~mm}$ of rainfall per year) with a rainy season from May to October. The temperature varies between $15^{\circ} \mathrm{C}$ and $45^{\circ} \mathrm{C}$ [10]. Three localities, namely Guelo, Pala and Gagal, were chosen in relation to this area, which is recognised as a groundnut production basin in the Sudanian zone of Chad (Figure 1).

Data collection on post-harvest operations was carried out with the help of a production survey sheet from the three localities of the province of Mayo Kebbi Ouest during the period from September to December 2020. These are the producers of Pala, Gagal and Guelo. Each producer was interviewed based on a questionnaire relating to drying and storage techniques, harvesting losses and 


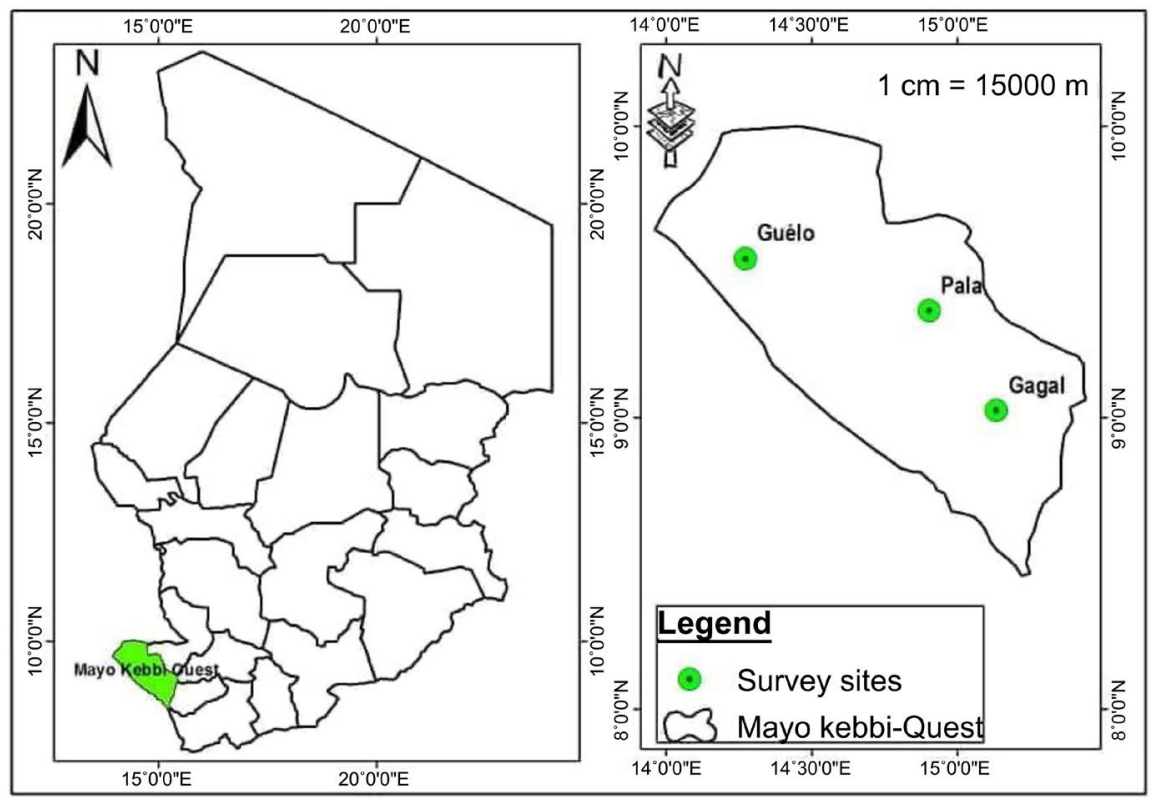

Figure 1. Survey area, West Mayo Kebbi province.

the use of the harvest product. The survey covered 75 producers, 25 of which were from each locality. The data collected (harvest period, drying method, drying period, drying technique, storage technique, storage location, storage method, storage duration, level of loss, causes of loss, means of control, presence of fungi in the stock, use of harvested products, type of buyer and customer requirement) were first processed manually and then coded using IBM SPSS Statistics Version 21 software. The qualitative variables were digitally coded $(1=$ whole groundnut plant and 2 = groundnut pod). The coded data were subjected to descriptive statistical analysis in terms of percentage and mean. The Chi-square test was used to determine the correlation between the variables analyzed (drying techniques, storage technique, use of the crop product according to the method of [6].

\section{Results}

Analyses of farmers' opinions in West Mayo Kebbi province show that $74.7 \%$ of them harvest their groundnuts in September compared to only $25.3 \%$ in October (Figure 2(a)). Also, 28\% of farmers admitted to drying their crops in the field, $9 \%$ use tarpaulins, $8 \%$ bring their crops back to the villages before drying them, while $54 \%$ use other means of drying such as cleaning the soil as drying air (Figure 2(c)). The Chi-square test $\left(\mathrm{X}^{2}=0.33 ; \mathrm{P}=0.0001\right)$ showed that there is a close link between the time (month) of harvest and the drying technique. Indeed, after harvesting, farmers dry their crops in a period of one week (73.3\%) with whole plants $(73.3 \%)$ while others dry only the pods $(26.7 \%)$.

The farmers surveyed stated that groundnuts keep better in pods (96\%) than in grain (4\%) (Figure 3(a)) and that the most used storage location is the shop (44\%), followed by the granary (25.3\%) (Figure $3(\mathrm{~b})$ ). A minority use the dwelling 


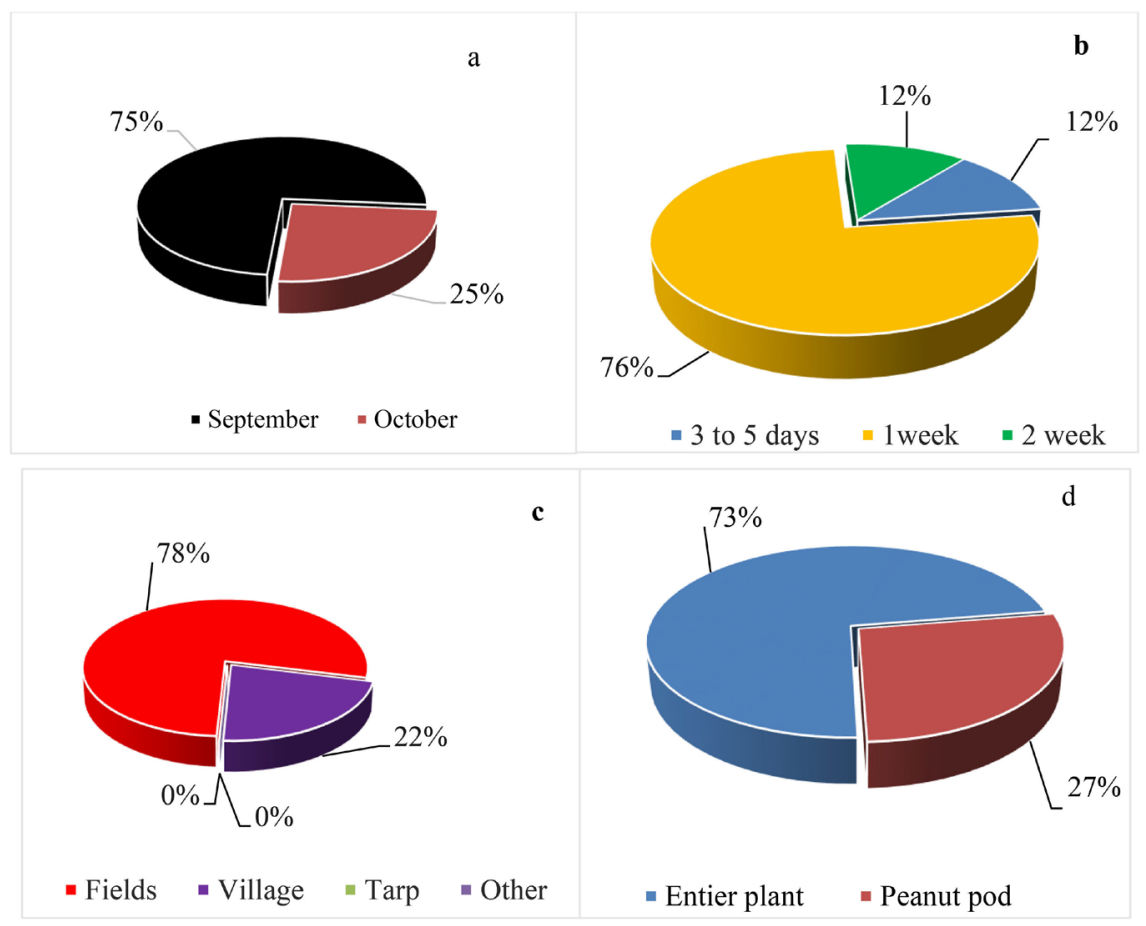

Figure 2. Harvest month (a), drying period (b), drying method (c) and drying technique (d).

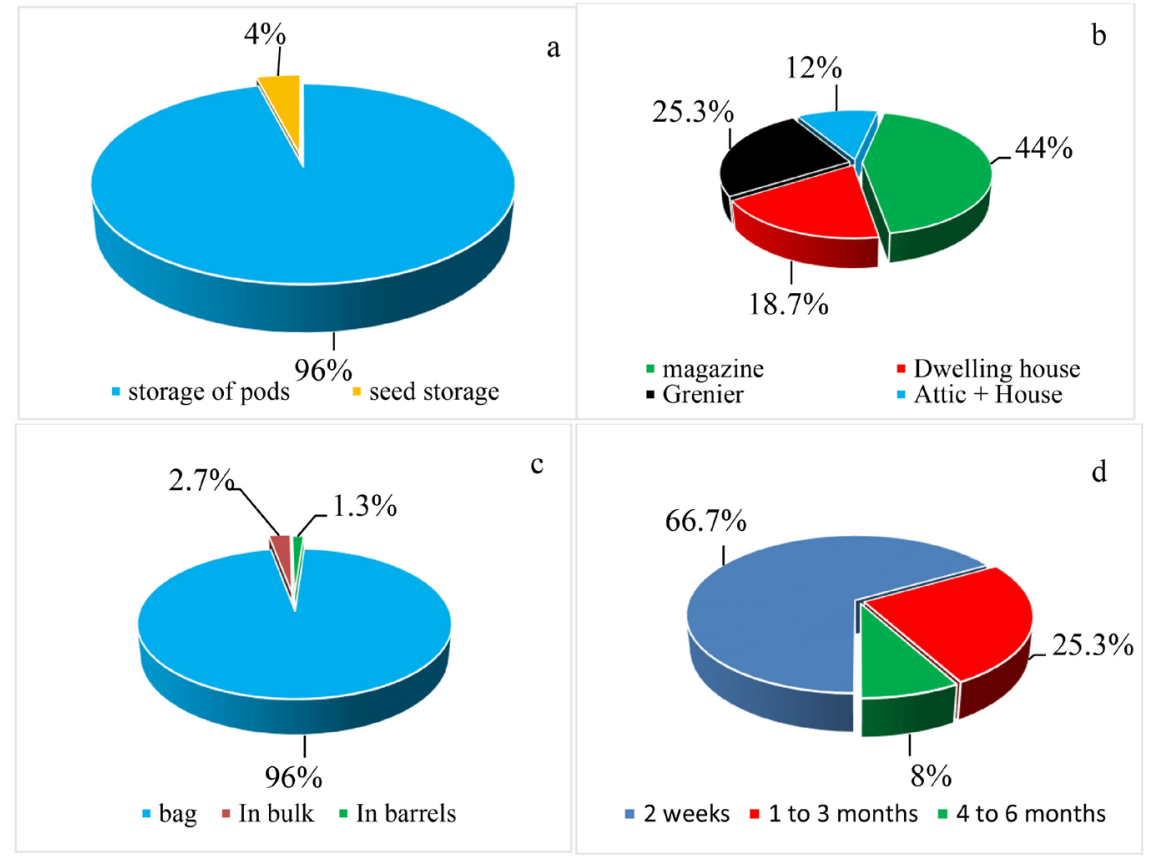

Figure 3. Technique (a), location (b), mode (c) and storage time (d).

house $(18.7 \%)$ as a storage place; some of them prefer to combine the granary and the dwelling house (12\%) to conserve their harvest products. Most farmers said they use bags (96\%) to store their groundnut crops, while others use barrels $(1.3 \%)$ or bulk storage $(2.7 \%)$ (Figure $3(\mathrm{c})$ ). The duration of storage (Figure 
$3(d))$ is spread over 6 months, with $66.7 \%$ of farmers keeping their crops for 2 weeks before selling them, while others keep them for $1-3$ months (25.3\%) and some go up to 4 - 6 months (8\%) before selling them on the market. The Chi-square test showed that there is a relationship between the drying method $\left(\mathrm{X}^{2}=132.56 ; \mathrm{P}=0.0001\right)$ and the storage duration $(0.0001<0.05)$.

The analysis carried out shows that the level of post-harvest losses of $2 \%-10 \%$ is $74.7 \%$ compared to $25.3 \%$ for losses that vary between $10 \%-50 \%$ (Figure 4(b)). Farmers confessed that most of the losses in groundnut production are caused by diseases observed on the leaves of the plants $(60 \%)$, the presence of insects seen in the fields and warehouses (32\%) and on the seeds that germinate (8\%) after harvest (Figure 4(a)).

According to farmers' opinions, about $69.3 \%$ of their crops show the presence of mould. Groundnuts produced in West Mayo Kebbi province are primarily for sale $(77.3 \%)$, some are consumed by the farmers themselves (4\%), and some farmers (18.7\%) also consume and sell their crops (Figure 5(b)). Analysis of the Chi-square Test $\left(\mathrm{X}^{2}=42.7 ; \mathrm{P}=0.0001\right)$ showed that there is a link between the drying world, the place of storage and the customers' requirements. In fact, the groundnuts produced in these three localities are mainly intended for traders (76\%), intermediaries (16\%) and local consumers (5.3\%). These buyers demand oil-producing varieties (60\%), non-mouldy grains (28\%) and non-harvested grains (Figure 5(a)).

\section{Discussion}

The information collected from farmers in the province of Mayo Kebbi West has made it possible to identify crop management techniques that can affect the nutritional quality of groundnuts due to mycotoxins. Harvesting practices such as drying, and storage condition cause the proliferation of saprotrophic fungi responsible to produce mycotoxins. In these localities (Gagal, Pala and Guélo) the pods are dried with the whole groundnut plants on the unprotected soil by most farmers after harvesting for one to two weeks. The contact of the pods with moist soil (rainy season), dew and the heat of the sun expose the crops to attacks by bio-aggressors which in turn lead to mould growth. These results corroborate
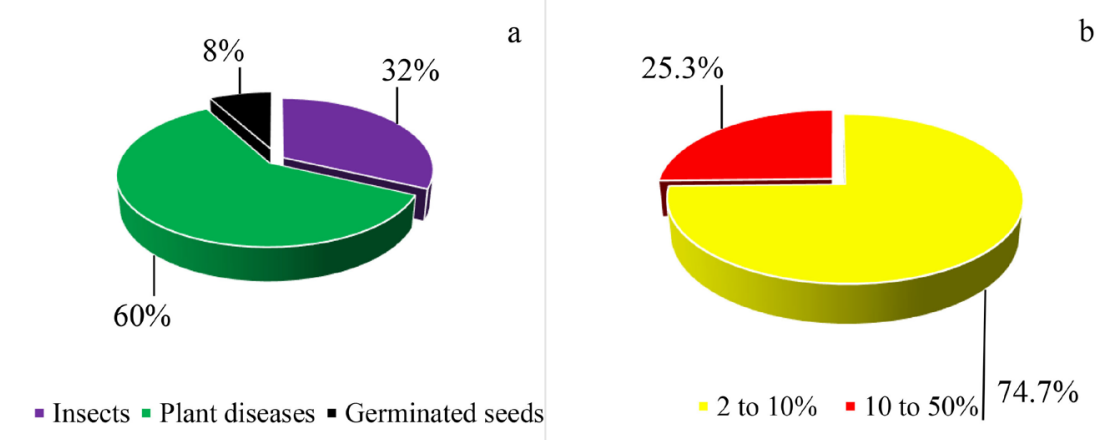

Figure 4. Cause of losses (a) and levels of losses location (b). 


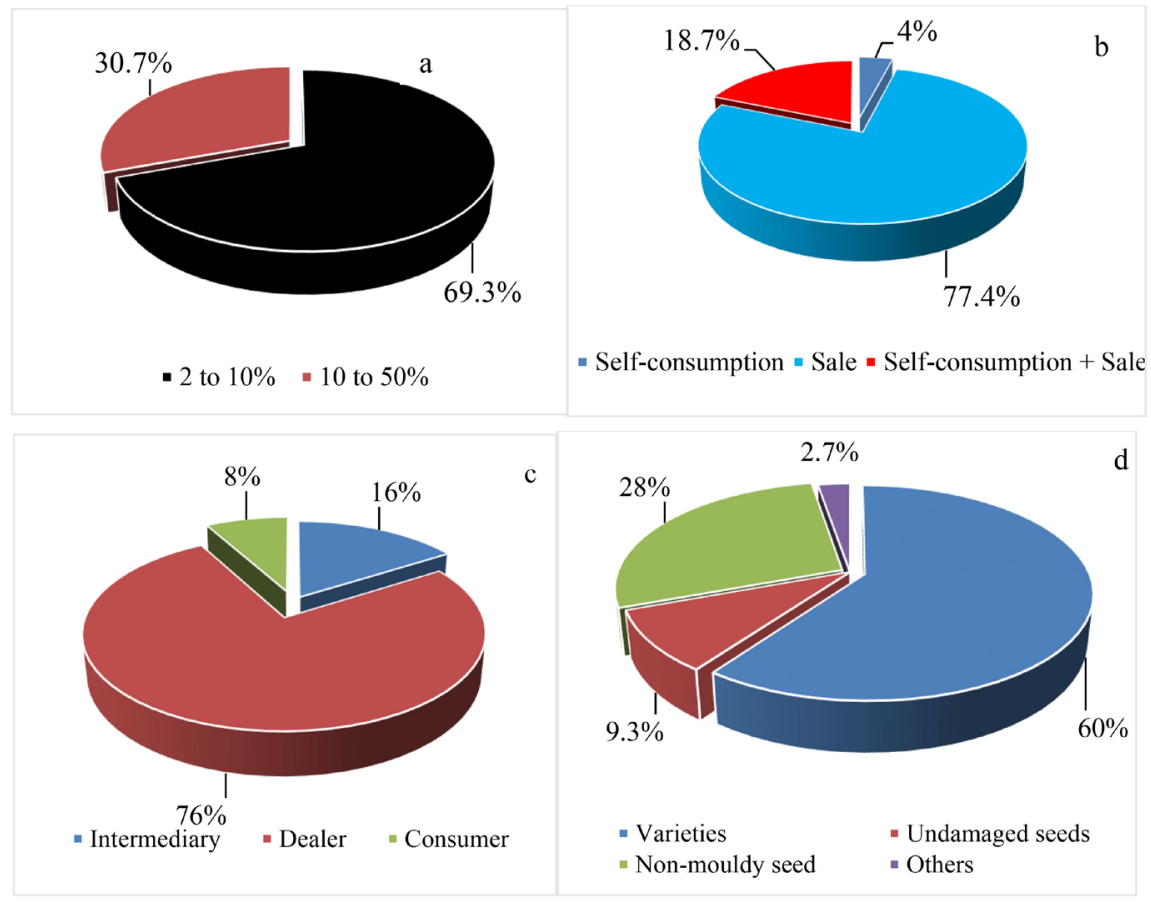

Figure 5. Presence of mould (a), crop use (b), different buyers (c) and customer requirements (d).

those of [8], who showed that in Benin post-harvest aflatoxin contamination increased when the harvest took more than 5 days and drying was delayed. A long drying period in the field leads to seed deterioration and mould growth [11]. In West Mayo Kebbi province, most farmers keep groundnuts in shell or with the pods in polythene bags to limit bio-aggressor attacks in the shop (44\%), the granary $(25.3 \%)$, the dwelling house (18.7\%) and both the granary/household (12\%). These storage places are in a precarious condition and are poorly ventilated. This lack of aeration would be the cause of a variation in temperature and humidity resulting from the physiological activity of the seeds, which would lead to the development of moulds and saprotrophic fungi. The work of [12] in Ghana showed that $81 \%$ of the farmers by storing their groundnut crop in polyethylene bags reduced mould attacks. However, there is a link between the location of storage of the Arachis hypogaea crop and the development of mycotoxins. In these different localities, the storage period is spread over 6 months, with $66.7 \%$ of farmers keeping their crops for 2 weeks before sale, and a small number of farmers keeping them for 1 to 3 months (25.3) and 4 to 6 months (8\%). This long shelf-life is a function of market demand, as farmers wait for price inflation before releasing their produce. The analysis carried out among farmers showed that the level of post-harvest losses of $2 \%$ to $10 \%$ is $74.7 \%$ and $10 \%$ to $50 \%$ is $25.3 \%$. These losses are due to plant diseases $(60 \%)$, the presence of insects on their crops (32\%) or seeds germinating (8\%) after harvesting due to heavy rains. These results are like those reported by [6] in Côte d'Ivoire. Indeed, the diseases encountered on groundnut plants are thought to be responsible for the weaken- 
ing of the plant and consequently for the disruption of the physiology of groundnut plants. According to [13], insect damage leaves openings that favor the penetration of larvae, fungal sclerotia. Most farmers interviewed admitted that groundnuts produced are mainly for marketing and little for consumption. Buyers demand as sales criteria the oil-producing variety (60\%), non-mouldy grains $(28 \%)$ and non-harvested grains. These results show that groundnuts produced in Mayo Kebbi West Province are largely exploited for local consumption and for export to neighboring countries such as Cameroon, Nigeria and the Central African Republic.

\section{Conclusion}

Post-harvest operations at risk of contamination by saprotrophic fungi in the groundnut sector of West Mayo Kebbi in Chad are linked to the harvest period, the drying conditions (duration and drying place) and storage (place and layout). These practices are responsible not only for the rotting of seeds but also for the invasion of seeds by moulds and mycotoxins. Indeed, the drying and storage practices used by farmers in the province of Mayo Kebbi West expose groundnuts to the development of molds responsible to produce mycotoxins and consequently affect the quality of the seeds for trading and consumption. The results reported in this study are a milestone in the aflatoxin contamination of groundnuts. It would be interesting to sensitize farmers in this part of Chad on techniques to preserve the sanitary quality of groundnuts and to study the harmful effect of aflatoxin mycotoxins in food.

\section{Conflicts of Interest}

Authors declare no conflict of interest regarding the publication of the paper.

\section{References}

[1] Touroumgaye, G., Diaollo, D., Madjimbe, G. and Guisse, A. (2017) Détermination de la densité optimale de semis sur la productivité d'arachide (Arachis hypogaea L.) en zone soudanienne du Tchad. European Scientific Journal, 13, 316-324. https://doi.org/10.19044/esj.2017.v13n9p316

[2] FAOSTAT (2018) Statistical Databases Accessed February 2020. http://faostat.fao.org/site/342/default.aspx

[3] Griel, A.E, Brenda, E., Juturu, V., Hsieh, G. and Penny, M.K.-E. (2004) Improved Diet Quality with Peanut Consumption. Journal of the American College of Nutrition, 23, 660-668. https://doi.org/10.1080/07315724.2004.10719408

[4] Albert, C.M., Michael, G., Walter, C.W. and JoAnn, E.M. (2002) Nut Consumption and Decreased Risk of Sudden Cardiac Death in the Physicians' Health Study. Archives of Internal Medicine, 162, 1382-1387. https://doi.org/10.1001/archinte.162.12.1382

[5] Briend, A. (2001) Highly Nutrient-Dense Spreads: A New Approach to Delivering Multiple Micronutrients to High-Risk Groups. British Journal of Nutrition, 85, S175. https://doi.org/10.1079/BJN2000311 
[6] Manizana, A.L., Akakid, D., Piro-Metayerc, I., Montetc, D., Brabetc, C. and Koffi-Nevrya, R. (2018) Évaluation des pratiques post récolte favorable à la contamination de l'arachide par les mycotoxines dans trois régions de Côte d'Ivoire. Journal of Applied Biosciences, 124, 12446-12454. https://doi.org/10.4314/jab.v124i1.6

[7] Kouadio, J.H., Lattanzio, V.M.T., Ouattara, D., Kouakou, B. and Visconti, A. (2014) Assessment of Mycotoxin Exposure in Côte D'Ivoire (Ivory Coast) through Multi-Biomarker Analysis and Possible Correlation with Food Consumption Patterns. Toxicology International, 21, 248-257. https://doi.org/10.4103/0971-6580.155336

[8] Hell, K., Cardwell, K.F., Setamou, M. and Poehling, H.M. (2000) The Influence of Storage Practices on Aflatoxin Contamination in Maize in Four Agroecological Zones of Benin. West Africa Journal of Stored and Production Resources, 36, 365-382. https://doi.org/10.1016/S0022-474X(99)00056-9

[9] Riley, R.T. and Norred, W.P. (1999) Mycotoxin Prevention and Decontamination. A Case Study on Maize. Alimantatio Nutrition et Agriculture, FAO, 23, 25-31.

[10] Gaouna, B.O. and Assane, S. (2009) Contribution à une amélioration de la gestion de l'enherbement dans des systèmes de production à dominance riz dans le terroir de Gang-Léo Baktana, au Tchad. Actes du colloque «Savanes africaines en développement: innover pour durer», Garoua, Cameroun, 10 p.

[11] FAO (2002) UEMOA-COTE D'IVOIRE: Appui à la mise en œuvre de la Politique agricole de l'Union en matière de sécurité alimentaire. Programme régional de sécurité alimentaire (FAO), $31 \mathrm{p}$.

[12] Akoua, A.-G. (2013) The Role of Women in Post-Harvest Handling of Peanuts: The Case of Reducing Aflatoxin along the Supply Chain in Ghana. MS Thesis, Alabama: Graduate Faculty of Auburn University, 46 p.

[13] Thiaw, C., Coly, E., Djiba, S., Diop, M., Ndoye, O., Cisse, N. and Sembene, M. (2015) Senna occidentalis L., une plante prometteuse dans la lutte contre Caryedon serratus Ol. (Coleoptera, Bruchidae), insecte ravageur des stocks d'arachide au Sénégal. International Journal of Biological and Chemical Sciences, 9, 1399-1418. https://doi.org/10.4314/ijbcs.v9i3.24 